\title{
PENGARUH BANTUAN HUKUM TERHADAP MASYARAKAT MISKIN (Meninjau Undang-Undang Nomor 16 Tahun 2011 tentang Bantuan Hukum)
}

The Influence of Legal Aid on the Poor (Reviewing the Law Number 16 Year 2011 on Legal Aid)

\author{
Ihdi Karim Makinara \\ Fakultas Syari'ah IAIN Ar-Raniry Banda Aceh \\ Jl. Nurudin Ar-Raniry Kopilima Darussalam Banda Aceh, Aceh \\ Email: ikmakinara@gmail.com
}

Naskah diterima: 23 April 2013; revisi: 25 April 2013; disetujui: 26 April 2013

\begin{abstract}
Abstrak
Bantuan hukum adalah salah satu upaya mengisi hak asasi manusia (HAM) terutama bagi lapisan masyarakat termiskin rakyat Indonesia. Bantuan hukum harus dimaknai dan dilaksanakan sebagai upaya perjuangan menegakkan HAM bagi si miskin. Tujuan bantuan hukum perlu diperluas, tidak saja terbatas pada bantuan hukum individual, tetapi juga struktural dan juga jangan terbelenggu dengan jalur-jalur formal semata. Dengan diundangkan Undang-Undang Nomor 16 Tahun 2011 tentang Bantuan Hukum memunculkan permasalahan bagaimana pengaruh bantuan hukum terhadap masyarakat? Dengan menggunakan metode penelitian normatif dan dengan pendekatan data secara kualitatif yang dianalisis deskriptif, didapatkan kesimpulan bahwa keberadaan Undang-Undang Bantuan Hukum belum maksimal memberikan pengaruh terhadap bantuan hukum bagi masyarakat miskin, karena bantuan hukum masih dalam jalur formalistik dan masih bersifat pasif. Pendanaan penyelenggaraan bantuan hukum yang digeser dari Mahkamah Agung, Kejaksaan Agung, dan Kepolisian kepada Menteri Hukum dan HAM dan dilaksanakan oleh Lembaga Bantuan Hukum atau Organisasi Kemasyarakatan agar dapat menyentuh orang atau kelompok orang miskin, tetapi besar anggaran perlu mempertimbangkan proses peradilan yang berjalan, karena dikhawatirkan dapat menghambat orang miskin dan kelompok orang miskin untuk mengakses keadilan guna mewujudkan hak-hak konstitusional mereka.

Kata Kunci: Bantuan Hukum, Masyarakat Miskin, Undang-Undang
\end{abstract}

\section{Abstract}

Legal aid is an effort to fulfill human rights, especially for Indonesian poorest society. Legal aid should be interpreted and implemented as an effort of human rights enforcement for the poor. The purpose of legal aid should be expanded, not just limited to individual legal assistance, but also structural and not fettered by mere formal channels. By enacted the Law Number 16 Year 2011 on Legal Aid, raises the question of how the influence of legal assistance to the society? By using normative research methods and approaches qualitative data were descriptively analyzed, was concluded that existence of legal aid has not been maximized effect to legal assistance for the poor, and because of it is still on formalistic track and passive. Funding of legal assistance shifted from the Supreme Court, Attorney General and Police to the Ministry of Justice and implemented by a Legal Aid Institution or civil society organization in order to reach people or the poor community, but the magnitude of budget needs to consider the judicial process, because it feared could hinder the poor to access of justice to realize their constitutional rights.

Keywords: Legal Aid, The Poor Community, The Law 


\section{A. Pendahuluan}

Bantuan hukum adalah salah satu upaya mengisi hak asasi manusia (HAM) terutama bagi lapisan masyarakat termiskin rakyat Indonesia. Orang kaya sering tidak membutuhkan bantuan hukum karena sebetulnya hukum itu dekat dengan orang kaya. Kekayaan memberikan perlindungan hukum yang lebih aman, malah sering juga melestarikan ketidakadilan hukum antara si kaya dan si miskin. ${ }^{1}$ Seseorang yang mampu membayar advokat kelas satu akan mendapatkan harapan sukses yang lebih besar dibandingkan dengan orang yang hanya mampu membayar seorang pokrol bambu. Seseorang yang mampu membayar dokter spesialis akan mempunyai harapan lebih besar dari seorang yang hanya mampu membayar seorang mantri, dan seorang lulusan universitas negeri akan mempunyai harapan lebih besar jika dibandingkan dengan seorang lulusan universitas swasta. Pengotak-kotakan memang telah menjadi sifat kehidupan. Rasa hormat atau kepercayaan terhadap "persamaan" adalah omong kosong kaum intelektual. Ini semua adalah contoh dari ketidakjujuran kita terhadap diri kita. ${ }^{2}$

Dengan alasan pikir yang demikian, bantuan hukum harus dimaknai dan dilaksanakan sebagai upaya perjuangan menegakkan HAM bagi si miskin. Karena hak rakyat miskin telah cukup lama 'ditawan' oleh orang-orang kaya, dan HAM itu tidak diberikan begitu saja. Ini menunjukkan ketidakadilan, maka melalui bantuan hukum dengan pola hubungan yang lebih adil HAM dapat diberikan.
Oleh sebab itu, tujuan bantuan hukum perlu diperluas, tidak saja terbatas pada bantuan hukum individual dan bersifat kota, tetapi juga struktural. Karena masalah pelanggaran HAM seringkali menindas masyarakat miskin pedesaan. Sudah waktunya gerakan bantuan hukum secara aktif datang ke pedesaan dan mengerjakan pekerjaan bantuan hukum dalam arti seluas-luasnya. Hendaknya jangan terbelenggu dengan jalur-jalur formal semata, sebab banyak jalur-jalur informal yang sudah waktunya ditangani. Karena itu, bantuan hukum harus diartikan sebagai upaya membebaskan masyarakat miskin dari struktur yang menindas mereka. Kalau ini masalahnya, maka bantuan hukum harus mampu membuka mata dan perasaan orang miskin bahwa mereka adalah korban dari sistem sosial yang tidak adil. Kesadaran bahwa mereka miskin dan tertindas mesti dipompakan kepada mereka.

Kultur nrimo yang sudah mendarah daging pada mayoritas masyarakat kita harus diubah. Mereka miskin karena mereka dibuat miskin, bukan karena dilahirkan miskin. Kesempatan yang seimbang tidak pernah ada. ${ }^{3}$ Sumbersumber daya ekonomi dan politik sepenuhnya dikuasai oleh orang-orang kaya, dan ini memungkinkan orang-orang kaya tersebut jadi penentu kehidupan orang-orang miskin. Equality of opportunity adalah perlu, tetapi ini tidak akan berarti banyak jika tempat ancangancang tidak sama.

Dari sinilah kita bertolak bahwa tujuan bantuan hukum adalah mengubah pola

C.J.M. Schuyt, Keadilan dan Effektivitas dalam Pembangunan Kesempatan Hidup - penerbitan tidak bertanggal. Dalam awal tulisannya Schuyt bercerita mengenai tragedi Kapal TITANIC yang tenggelam di laut. Kapal yang terdiri dari 3 kelas itu memberikan bukti, bahwa penumpang kelas I lebih terjamin keselamatannya jika dibandingkan dengan penumpang kelas II dan kelas III, dan penumpang kelas II lebih terjamin dari penumpang kelas III. Kelebihan uang atau kekayaan ternyata memberikan jaminan keselamatan yang baik.

2 T. Mulya Lubis, "Pembangunan dan Hak-has asasi Manusia", Prisma No. 12, (Desember 1979): 11-20.

3 Mahbub ul Haq, The Poverty Curtain: Choice for the Third World, (New York, Columbia: University Press, 1976). 
struktur yang menindas, paling tidak meratakan jalan menuju suatu perubahan struktur yang menindas ke struktur yang lebih berkeadilan.

Dalam kaitan itu, telah disahkan dan diundangkan Undang-Undang Nomor 16 Tahun 2011 tentang Bantuan Hukum dalam konsiderannya menyatakan a) bahwa negara menjamin hak konstitusional setiap orang untuk mendapatkan pengakuan, jaminan, perlindungan, dan kepastian hukum yang adil serta perlakuan yang sama di hadapan hukum sebagai sarana perlindungan hak asasi manusia; b) bahwa negara bertanggung jawab terhadap pemberian bantuan hukum bagi orang miskin sebagai perwujudan akses terhadap keadilan; c) bahwa pengaturan mengenai bantuan hukum yang diselenggarakan oleh negara harus berorientasi pada terwujudnya perubahan sosial yang berkeadilan; dan d) bahwa berdasarkan pertimbangan sebagaimana dimaksud dalam huruf $a$, huruf, $b$, dan huruf $c$, perlu membentuk undang-undang tentang Bantuan Hukum.

\section{B. Permasalahan}

Dari uraian di atas, maka dalam tulisan ini penulis akan mengkaji bagaimana pengaruh bantuan hukum terhadap masyarakat miskin ditinjau dari Undang-Undang Nomor 16 Tahun 2011?

\section{Metode Penelitian}

\section{Pengumpulan Data}

Penelitian ini merupakan penelitian normatif, yaitu penelitian hukum yang dilakukan dengan cara meneliti bahan pustaka atau data sekunder. ${ }^{4}$ Data Sekunder dalam penelitian ini meliputi:

a. Bahan hukum primer, yaitu bahan-bahan hukum yang mempunyai kekuatan mengikat, ${ }^{5}$ seperti:

1) Undang-Undang Dasar Republik Indonesia Tahun 1945

2) Undang-Undang;

3) Peraturan perundang-undangan lainnya di bawah Undang-Undang.

b. Bahan hukum sekunder yaitu bahan-bahan yang erat hubungannya dengan bahan hukum primer dan dapat membantu dalam menganalisis dan memahami bahan hukum primer antara lain:

1) Hasil karya ilmiah (buku, makalah, tulisan di majalah hukum);

2) Hasil-hasil penelitian yang telah dipublikasikan.

\section{Analisis Data}

Analisis data adalah tahap yang paling penting dalam kegiatan penelitian, karena pada tahap ini berfungsi memberi interpretasi serta arti terhadap data yang telah diperoleh.

Dalam penelitian ini, data yang diperoleh disajikan secara kualitatif, dengan menggunakan analisis deskriptif, yaitu dengan mendeskripsikan data yang diperoleh ke dalam bentuk penjelasanpenjelasan. ${ }^{6}$ Artinya problem yang ada dianalisis dan dipecahkan berdasarkan teori dan peraturan yang ada, serta dilengkapi analisis.

Soerjono Soekanto dan Sri Mamudji, Penelitian Hukum Normatif, (Jakarta: Rajawali Press, Jakarta, 1985), hlm. 5.

5 Ronny Hanitijo Soemitro, Metodologi Penelitian Hukum dan Jurimetri, (Jakarta: Ghalia Indonesia, 1990), hlm. 11.

6 Soerjono Soekanto dan Sri Mamudji, Penelitian Hukum Normatif, Op.Cit. 


\section{Pembahasan}

\section{Pengertian Bantuan Hukum}

Istilah bantuan hukum sebagai terjemahan dari dua istilah yang berbeda yaitu "legal aid" dan "legal Assistance". "Legal Aid" digunakan untuk menunjukkan pengertian bantuan hukum bagi orang miskin yang tidak mampu membayar advokat. Sedangkan "Legal Assistance" digunakan untuk menunjukkan pengertian bantuan hukum bagi masyarakat mampu dan tidak mampu oleh para Advokat yang mempergunakan honorarium. ${ }^{7}$ Dengan kata lain, "legal aid" adalah bantuan hukum dalam arti sempit, sebaliknya "legal assistance"adalah bantuan hukum dalam arti luas.

Bantuan hukum secara yuridis didefinisikan oleh Undang-Undang Nomor 16 Tahun 2011 tentang Bantuan Hukum, selanjutnya disebut UU Bantuan Hukum, sebagai berikut:

\footnotetext{
"Bantuan Hukum adalah jasa hukum yang diberikan oleh Pemberi Bantuan Hukum secara cuma-cuma kepada Penerima Bantuan Hukum." ${ }^{8}$

Di mana yang dimaksud dengan Pemberi Bantuan Hukum adalah lembaga bantuan hukum atau organisasi kemasyarakatan yang memberi layanan Bantuan Hukum berdasarkan Undang-Undang. ${ }^{9}$ Sedangkan yang dimaksud Penerima Bantuan Hukum adalah orang atau kelompok orang miskin. ${ }^{10}$
}

Dari pengertian tersebut dapat dipahami bahwa bantuan hukum dilakukan oleh Lembaga Bantuan atau Organisasi Kemasyarakatan terhadap orang miskin (perseorangan) maupun kelompok orang miskin yang menghadapi masalah hukum keperdataan, pidana, dan tata usaha Negara, baik litigasi maupun nonlitigasi. $^{11}$

Dalam pada itu, terkait makna "jasa hukum", sebagaimana telah ditentukan oleh UU Bantuan Hukum, sebagai 'bentuk' -nya meliputi: menjalankan kuasa, mendampingi, mewakili, membela, dan/atau melakukan tindakan hukum lain untuk kepentingan hukum orang miskin maupun kelompok orang miskin. ${ }^{12}$

Selanjutnya, eligibility (ukuran) kemiskinan, baik orang miskin atau kelompok orang miskin, adalah yang tidak dapat memenuhi hak dasar secara layak dan mandiri, seperti hak atas sandang, pangan, layanan kesehatan, layanan pendidikan, pekerjaan dan berusaha, dan/atau perumahan. ${ }^{13}$

Sebagai perbandingan, di dalam UndangUndang Nomor 18 Tahun 2003 tentang Advokat dinyatakan: "Bantuan hukum adalah jasa hukum yang
diberikan oleh Advokat secara cuma-cuma
kepada Klien yang tidak mampu."14
Dengan demikian, bantuan hukum dalam
arti "legal aid" diberikan dan dilakukan secara

Todung Mulya Lubis, Bantuan Hukum dan Kemiskinan Struktural, (Jakarta: LP3ES, 1986), hlm. 3.

8 Pasal 1 Angka 1 Undang-Undang Republik Indonesia Nomor 16 Tahun 2011 tentang Bantuan Hukum, Lembaran Negara Republik Indonesia, Tahun 2011 Nomor 104, Tambahan Lembaran Negara Republik Indonesia Nomor 5248.

9 Pasal 1 angka 2, Ibid.

10 Pasal 1 angka 3, Ibid.

11 Pasal 4 ayat (1) dan ayat (2), Ibid.

12 Pasal 4 ayat (3), Ibid.

13 Pasal 5, Ibid.

14 Pasal 1 Angka 9 Undang-Undang Republik Indonesia Nomor 18 Tahun 2003 tentang Advokat, Lembaran Negara Republik Indonesia Tahun 2003 Nomor 49, Tambahan Lembaran Negara Republik Indonesia Tahun 2003 Nomor 4288. 
cuma-cuma, khusus kepada masyarakat miskin atau tidak mampu secara ekonomi yang tidak mampu membayar jasa hukum.

\section{Bantuan Hukum Bagi Masyarakat Miskin Dalam Beragam Aturan}

Bantuan hukum bukan terminologi baru dalam dunia hukum Indonesia. Bahkan, "bantuan hukum" diatur dalam berbagai peraturan perundang-undangan. Lahirnya UU Bantuan Hukum menambah daftar peraturan perundang-undangan yang memuat tentang bantuan hukum. Meskipun memang peraturan perundang-undangan yang bersifat lex specialis baru ada setelah hadirnya undang-undang ini. Peraturan Perundang-undangan adalah peraturan tertulis yang memuat norma hukum yang mengikat secara umum dan dibentuk atau ditetapkan oleh lembaga negara atau pejabat yang berwenang melalui prosedur yang ditetapkan dalam Peraturan Perundangundangan. ${ }^{15}$

Dalam membentuk sebuah Peraturan Perundang-undangan harus dilakukan berdasarkan pada asas pembentukan peraturan perundang-undangan yang baik, yakni: ${ }^{16}$
a. Kejelasan tujuan
b. Kelembagaan atau pejabat pembentuk yang tepat
c. Kesesuaian antara jenis, hierarki, dan materi muatan
d. Dapat dilaksanakan
e. Kedayagunaan dan Kehasilgunaan
f. Kejelasan rumusan
g. Keterbukaan

Selain mencerminkan asas-asas tersebut, peraturan perundang-undangan tertentu dapat berisi asas lain sesuai dengan bidang hukum peraturan perundang-undangan yang bersangkutan.

Peraturan perundang-undangan yang mengatur secara khusus mengenai bantuan hukum adalah Undang-Undang Bantuan Hukum. Ketentuan lain mengenai bantuan hukum terdapat pula dalam Pasal 22 ayat (1) Undang-Undang Nomor 18 Tahun 2003 tentang Advokat yang menyebutkan bahwa Advokat wajib memberikan bantuan hukum secara cuma-cuma kepada pencari keadilan yang tidak mampu.

Secara lebih spesifik aturan ini termuat juga dalam Kode EtikPerhimpunan Advokat Indonesia (PERADI) Pasal 7 point $h$ bahwa Advokat mempunyai kewajiban untuk memberikan bantuan hukum secara cuma-cuma (pro deo) bagi orang yang tidak mampu. PERADI sendiri membentuk satu unit layanan bernama $\mathrm{PBH}$ Peradi, yang menerapkan kewajiban 50 jam per tahun untuk setiap advokat memberikan bantuan hukum pro bono. Terkait dengan bantuan hukum pro bono, negara melalui undang-undang peradilan umum, peradilan agama dan TUN menjadikan Posbakum ${ }^{17}$ sebagai wadah untuk bantuan hukum bagi orang tidak mampu.

Selain itu, Pemerintah telah mengeluarkan Peraturan Pemerintah Nomor 83 tahun 2008 tentang Persyaratan dan Tata Cara Pemberian Bantuan Hukum secara cuma-cuma. Bantuan hukum cuma-cuma adalah jasa hukum yang

Pasal 1 Undang-Undang Republik Indonesia Nomor 12 Tahun 2011 tentang Pembentukan Peraturan Perundangundangan.

16 Pasal 5 Undang-Undang Nomor 12 Tahun 2011, Ibid.

17 Posbakum merupakan akronim dari Pos Bantuan Hukum. 
diberikan advokat tanpa menerima pembayaran honorarium meliputi pemberian konsultasi hukum, menjalankan kuasa, mewakili, mendampingi, membela, dan melakukan tindakan hukum lain untuk kepentingan pencari keadilan yang tidak mampu. ${ }^{18}$ Definisi pencari keadilan yang tidak mampu adalah orang perseorangan atau sekelompok orang yang secara ekonomis tidak mampu yang memerlukan jasa hukum untuk menangani dan menyelesaikan masalah hukumnya.

Bantuan hukum bisa ditemukan dalam Instruksi Menteri Kehakiman Republik Indonesia Nomor: M.03-UM.06.02 Tahun 1999 yang menegaskan bahwa yang termasuk orang kurang mampu adalah orang-orang yang mempunyai penghasilan yang sangat kecil, sehingga penghasilannya tidak cukup untuk membiayai perkaranya di pengadilan, keadaan ketidakmampuan ini ditentukan oleh Ketua Pengadilan Negeri berdasarkan keterangan Kepala Desa atau Lurah.

Aturan-aturan hukum yang mengamanatkan untuk pemberian bantuan hukum kepada para pencari keadilan yang tidak mampu dapat dilihat juga dalam Undang-Undang Nomor 48 Tahun 2009 Tentang Kekuasaan Kehakiman, serta pada Undang-Undang Nomor 49 Tahun 2009 Tentang Peradilan Umum yang dibahas di Pasal 68B dan Pasal 68C, yang isinya adalah setiap orang yang berperkara mendapatkan bantuan hukum, Negara yang menanggung biaya perkara tersebut, pihak yang tidak mampu harus melampirkan surat keterangan tidak mampu harus melampirkan surat keterangan tidak mampu dari kelurahan tempat domisili yang bersangkutan, serta setiap Pengadilan
Negeri agar dibentuk Pos Bantuan Hukum kepada para pencari keadilan yang tidak mampu dalam memperoleh bantuan hukum secara cuma-cuma kepada semua tingkat peradilan sampai putusan terhadap perkara tersebut memperoleh kekuatan hukum tetap.

Hak atas bantuan hukum adalah bagian dari proses peradilan yang adil dan inherent di dalam prinsip negara hukum dan merupakan salah satu prinsip HAM yang telah diterima secara universal. Hal ini dinyatakan dalam Pasal 7 Deklarasi Umum Hak Asasi Manusia (DUHAM), yang menjamin persamaan kedudukan di muka hukum dan dijabarkan dalam International Covenant on Civil dan Political Rights (ICCPR) atau Konvensi Hak Sipil dan Politik. Pasal 16 dan Pasal 26 ICCPR menjamin bahwa semua orang berhak untuk perlindungan dari hukum serta harus dihindarkan adanya diskriminasi berdasarkan apapun termasuk status kekayaan. Sedangkan Pasal 14 ayat (3) menjamin hak atas bantuan hukum dan memerintahkan negara untuk menyediakan Advokat/Pemberi Bantuan Hukum (PBH) yang memberikan bantuan hukum secara efektif untuk masyarakat miskin dan ketika kepentingan keadilan mensyarakatkannya.

Selain DUHAM dan ICCPR, hak atas bantuan hukum terdapat dalam UN Standard Minimum Rules for the Administration of Juvenile Justice, terkait pentingnya hak atas bantuan hukum bagi anak yang berkonflik dengan hukum, UN Declaration on the Rights of Disabled Persons terkait pentingnya bantuan hukum yang berkualitas pada orang-orang difable (different ability). Hak Bantuan hukum dikategorikan sebagai non-derogable rights (tak dapat dikurangi).

18 Pasal 1 Peraturan Pemerintah Nomor 83 tahun 2008 tentang Persyaratan dan Tata Cara Pemberian Bantuan Hukum secara cuma-cuma. 
Secara khusus hak bantuan hukum dijamin dalam Pasal 17, 18, 19 dan 34 Undang-Undang Nomor 39 Tahun 1999 tentang HAM, UndangUndang Nomor 14 Tahun 1970 tentang Ketentuan Pokok Kekuasaan Kehakiman, dengan perubahannya dalam Undang-Undang Nomor 35 Tahun 1999, khususnya Pasal 35 yang menyatakan setiap orang yang tersangkut perkara berhak memperoleh bantuan hukum.

Hak ini melekat pada perumusan hak tersangka/terdakwa, saksi dan korban dalam berbagai peraturan perundang-undangan yang bersifat sektoral, seperti dalam UndangUndang Nomor 8 Tahun 1981 tentang Kitab Undang-Undang Hukum Acara Pidana (KUHAP), Undang-Undang Nomor 12 Tahun 2005 tentang Konvensi Hak Sipil dan Politik, Undang-Undang Nomor 7 Tahun 1984 tentang Ratifikasi CEDAW, Undang-Undang Nomor 23 tahun 2002 tentang Perlindungan Anak, Undang-Undang Nomor 13 Tahun 2006 tentang LPSK dan Undang-Undang tentang Perdagangan Orang.

Pada awalnya, perihal bantuan hukum telah diatur dalam beberapa pasal dalam Herziene Indische Reglement (HIR). Pengaturan bantuan hukum tersebut merupakan bagian dari kegiatan pelayanan hukum. Secara khusus, pengaturan tentang pelayanan hukum bagi golongan masyarakat yang tidak mampu, dalam arti tidak mampu untuk membayar ongkos perkara dan honorarium bagi advokat diatur dalam Pasal 237 HIR sampai dengan Pasal 242 HIR dan Pasal 250 HIR.

Pasal 237 HIR sampai dengan Pasal 242 HIR mengatur tentang permohonan untuk berperkara di pengadilan tanpa membayar ongkos perkara. Sedangkan Pasal 250 HIR secara khusus mengatur ketentuan tentang hak untuk memperoleh pelayanan hukum secara cuma-cuma bagi mereka yang miskin yang terlibat dalam perkara pidana. Dalam perkembangannya, maka pengaturan bantuan hukum juga telah diatur dalam berbagai bentuk peraturan mulai dari undang-undang sampai dengan Surat Keputusan.

Sebagaimana yang dijelaskan dalam Pasal 35, Pasal 36 dan Pasal 37 Undang-Undang Nomor 14 Tahun 1970 tentang KetentuanKetentuan Pokok Kekuasaan Kehakiman berikut dengan perubahannya dalam Undang-Undang Nomor 35 Tahun 1999 menegaskan bahwa setiap orang yang terlibat dalam perkara berhak untuk memperoleh bantuan hukum baik dalam perkara pidana ataupun perdata.

Terdapat tiga dasar pemikiran utama untuk mengkonsolidasikan kebijakan pemerintah dan peraturan hukum dalam sebuah strategi nasional untuk keadilan yang jelas dan koheren ${ }^{19}$ yaitu:

1. Reformasi Kelembagaan. Reformasi kelembagaan seharusnya responsif terhadap kebutuhan masyarakat. Sebuah strategi nasional akan menghubungkan permintaan masyarakat akan pelayanan hukum yang lebih baik guna menjawab kebutuhan segenap masyarakat Indonesia, mencakup lembaga keadilan formal dan informal.

2. Keadilan dan Kemiskinan. Meningkatkan akses hukum dan keadilan akan melengkapi upaya pemerintah untuk menanggulangi kemiskinan dan pemberdayaan masyarakat.

3. Justice dan Security. Meningkatkan efektifitas dan kepercayaan terhadap sistem hukum yang pada giliranya dapat mengurangi konflik dan memperbaiki jaminan keamanan masyarakat.

19 http://hukum.kompasiana.com/2012/08/07/mengurai-uu-bantuan-hukum-2-483159.html 
Menurut Adnan Buyung Nasution, ${ }^{20}$ upaya yang dimaksud memiliki tiga aspek yang saling berkaitan:

1. Aspek perumusan aturan-aturan hukum.

2. Aspek pengawasan terhadap mekanisme untuk menjaga aturan-aturan tersebut untuk ditaati dan dipatuhi.

3. Aspek pendidikan masyarakat agar aturanaturan tersebut dipahami.

Karenanya bantuan hukum dimaknai secara meluas, dengan tidak hanya terbatas pada pemberian pelayanan dan pendampingan bagi masyarakat miskin dalam sistem hukum baik di dalam maupun di luar peradilan, namun juga diharapkan, (1) Adanya pengetahuan dan pemahaman masyarakat miskin tentang kepentingan-kepentingan bersama mereka. (2) Adanya pengertian bersama di kalangan masyarakatmiskintentangperlunyakepentingankepentingan mereka dilindungi oleh hukum. (3) Adanya pengetahuan dan pemahaman di kalangan masyarakat miskin tentang hakhak mereka yang telah diakui oleh hukum. (4) Adanya kecakapan dan kemandirian di kalangan masyarakat miskin untuk mewujudkan hak-hak dan kepentingan-kepentingan mereka di dalam masyarakat.

Dengan kata lain, seharusnya bantuan hukum tidak saja dalam proses peradilan, tetapi justru suatu proses pendidikan hukum (legal education): bagaimana menumbuhkan suatu kesadaran hukum (legal conciousness) agar masyarakat mengerti akan hak-hak dan kewajibannya dalam pergaulan hukum di masyarakat. Proses pendidikan hukum ini bisa diartikan sebagai usaha untuk mengintrodusir nilai-nilai baru yang berguna tidak saja secara hukum, tetapi menyangkut banyak segi lain, lebih-lebih aspek ekonomis, terutama kalau kita hubungkan dengan kenyataan-kenyataan sosial, bahwa kita memang sedang menuju ke arah pertumbuhan ekonomi yang sejalan dengan pembagian pendapatan yang merata sesuai dengan sila keadilan social bagi seluruh rakyat Indonesia. ${ }^{21}$

Dalam ketentuan peralihan UU Bantuan Hukum dijabarkan bahwa pada tahun 2013 Kementerian Hukum dan Hak Asasi Manusia (Kemenkumham) akan secara penuh melaksanakan tugas dan fungsi sekaligus penganggarannya pada tahun 2013. Dalam ketentuan penutup Pasal 24 disebutkan bahwa: "Pada saat undang-undang ini mulai berlaku, semua peraturan perundang-undangan yang mengatur mengenai bantuan hukum dinyatakan masih tetap berlaku sepanjang tidak bertentangan dengan ketentuan dalam undangundang ini".

\section{Konsep Bantuan Hukum}

Ada dua konsep pokok dalam bantuan hukum, yaitu konsep bantuan hukum individual dan konsep bantuan hukum struktural. ${ }^{22}$ Konsep bantuan hukum individual (tradisional) pada dasarnya suatu konsep lama yang sejalan dengan sistem hukum yang ada: bantuan hukum pada setiap kasus yang menurut hukum beralasan untuk dibela. Penekannya pada hukum itu sendiri, hukum yang selalu diandaikan netral, sama rasa sama rata. Permasalahannya, cukup sering hukum itu tidak memberikan keadilan. Hukum dalam posisi netral cukup sering justru

20 Adnan Buyung Nasution, Bantuan Hukum di Indonesia, (Jakarta: LP3ES, 1981), hlm 45.

21 Todung Mulya Lubis, "Bantuan Hukum: Arti Dan Peranannya", Prisma No. 6 Tahun II, (Desember 1973 ): 1.

22 Ibid, hlm. 84-86. 
menguntungkan mereka yang berkuasa dan berpunya ${ }^{23}$, dan merugikan mayoritas rakyat miskin.

Berlawanan dengan itu, konsep bantuan hukum struktural mencoba mengaitkan kegiatan bantuan hukum seperti itu dengan upaya merombak tatanan sosial yang tidak adil. Jadi sasarannya tidak lagi sekedar membantu individual dalam sengketa yang dihadapinya, tetapi lebih mengutamakan sengketa yang punya dampak struktural.

Karena itu, bantuan hukum harus dijadikan kekuatan pendorong ke arah tercapainya perombakan tatanan sosial, sehingga akan memiliki pola hubungan yang adil. Hukum sering tidak menjawab tantangan yang dihadapi, malah turut mengukuhkan status quo, karena hukum diandaikan netral. Kritik terhadap tatanan sosial sebagai tidak adil, tidak seimbang, maka kenetralan sama artinya keberpihakan pada tatanan yang ada. ${ }^{24}$ Si miskin dan si lemah tidak akan berdaya menghadapi si kaya dan si kuat. Di sini tempat bantuan hukum struktural harus berpihak pada si miskin dan si lemah yang merupakan mayoritas. Karena itu, arti "keadilan", "keadilan sosial" dan "keadilan struktural" harus dilihat dari segi appearance dan essence.

Todung melanjutkan, pagar-pagar (perangkap) yang melingkari bantuan hukum. Pertama, masin dominannya konsep bantuan hukum individual. Kedua, keterperangkapan kita kepada keadilan formal (appearance). Dan ketiga, keterikatan kita terhadap upaya hukum (legal means)..$^{25}$
Dalam sengketa-sengketa yang bersifat permukaan, bantuan hukum berikut dana tersedia untuk mencari jalan keluar. Bantuan hukum hanya menjadi semacam pelayanan medis bagi orang sakit.

Karena itu, bantuan hukum individual saja tidak cukup. Orang miskin atau kelompok orang miskin harus dikembalikan hak-hak dasar mereka akan sumber-sumber daya politik, ekonomi, teknologi, informasi dan sebagainya, agar mereka bisa menentukan masyarakat bagaimana yang mereka kehendaki.

Beberapa alasan mengapa bantuan hukum tradisional (individual) tidak cukup, sebagaimana dikemukakan Todung Mulya Lubis, ${ }^{26}$ antara lain:

1. Sifat bantuan hukum tradisional adalah individual. Asal seseorang itu bisa membuktikan dirinya tidak sehat atau buta hukum dan miskin, maka orang tersebut punya hak untuk diobati atau diberi bantuan hukum;

2. Sistem hukum kita menunjang sistem bantuan hukum tradisional dan individual;

3. Bantuan hukum masih sangat bersifat kekotaan, dan karena itu masih diragukan apakah bantuan hukum kita berhubungan dengan masyarakat-masyarakat pinggiran;

4. Sifat hukum kita pasif, atau menunggu, menyadari kemiskinan dan keterasingan rakyat pinggiran atas sumber-sumber daya politik, ekonomi, teknologi dan informasi. Sifat hukum yang pasif ini sebetulnya lebih berperan sebagai legitimasi status quo yang mempertahankan pola hubungan yang menindas;

\footnotetext{
23 Lihat C.J.M. Schuyt, "Keadilan dan Efektifitas dalam Pembangunan Kesempatan Hidup", Op.Cit.

24 Todung Mulya Lubis, Bantuan Hukum dan Kemiskinan Struktrural, Op.Cit., hlm. 85.

25 Ibid. hlm. 86.

26 Ibid, hlm. 52-55.
} 
5. Bantuan hukum masih terlalu terikat dengan pendekatan-pendekatan hukum semata, maka kurang diperhatikan pendekatan yang bukan hukum yang justru bisa membantu percepatan penyelesaian sengketa atau malah konflik sosial;

6. Bantuan hukum masih berjalan sendiri, atau baru pada tahapan bekerjasama dengan sesama organisasi bantuan hukum.

7. Bantuan hukum belum mengarah pada terciptanya gerakan sosial. Seharusnya dalam gerakan bantuan hukum arah akan konsientisasi sosial, politik, ekonomi dan hukum dikaitkan juga dengan upaya penciptaan suatu power resources.

Ketujuh alasan di atas, menjadi dasar untuk merombak dari konsep bantuan hukum individual menuju konsep bantuan hukum struktural. Beberapa ciri yang dimiliki konsep bantuan hukum struktrural, ${ }^{27}$ antara lain:

1. Sifat bantuan hukum harus struktural. Artinya bantuan hukum harus mengutamakan bantuan kepada kelompok bukan, bukan lagi perorangan;

2. Sistem hukum kita harus diubah dalam arti aksi-aksi kelompok atau aksi hukum struktural harus mulai dimungkinkan;

3. Sifatbantuan hukum harusmenjadipedesaan disamping tetap berurusan dengan kota. Karena lapisan masyarakat yang justeru sering tertindas lebih banyak di pedesaan.

4. Sifat bantuan hukum haruslah aktif. Karena bantuan hukum bukan lagi rumah sakit yang menunggu, tetapi haruslah bantuan hukum berjalan dari satu tempat ke tempat di kota dan di desa.

5. Bantuan hukum harus mulai mendayagunakan pendekatan-pendekatan di luar hukum atau bukan hukum (extralegal approach);

6. Bantuan hukum haruslah membuka diri terhadap organisasi sosial bukan hukum. Karena suatu koordinasi kegaitan adalah jawaban yang harus ditempuh.

7. Bantuan hukum harus menjadigerakan sosial yang bertujuan tidak saja pada konsientisasi sosial, politik, ekonomi, dan budaya, tetapi justru harus menciptakan power resources untuk menghadapi yang menindas.

Dengan kata lain, jaminan terhadap bantuan hukum tidak berkaitan dengan adanya undangundang bantuan hukum. Ketika yang dibicarakan adalah bantuan hukum dalam konteks struktural, maka perlu juga diperhatikan upaya pengembangan kapasitas masyarakat untuk mampu menyelesaikan sendiri permasalahan hukum yang dihadapinya lewat ketentuan yang memungkinkan diterapkannya Alternative Dispute Resolution (ADR). Perlu juga diperhatikan jaminan terhadap hak masyarakat untuk mengembangkan pengetahuannya dan sikap kritis terhadap setiap produk hukum negara maupun yurisprudensi yang dihasilkan pengadilan, dengan adanya ketentuan mengenai kebebasan mendapatkan informasi, serta berbagai ketentuan lain yang akan memberi iklim kondusif bagi terselenggaranya bantuan hukum individual maupun struktural.

Bantuan hukum individual seperti yang dikatakan sebelumnya, lebih tertuju pada kegiatan pendampingan terhadap masyarakat dalam menyelesaikan masalahnya melalui proses hukum sehingga proses tersebut berjalan sebagaimana mestinya tanpa ada diskriminasi hukum terhadap mereka. Hal ini mengakibatkan perlunya kualifikasi tertentu, yaitu sarjana

Ibid, hlm. 55-57. 
hukum yang menjadi advokat, bagi pelaksana bantuan hukum individual. Sementara bantuan hukum struktural kegiatannya lebih mengarah kepada proses pemberdayaan dan penyadaran masyarakat hukum supaya mereka dapat memperjuangkan hak-haknya yang dilanggar pada cara tertentu.

Bantuan hukum struktural selama tidak bersentuhan langsung dengan proses peradilan dapat dilakukan oleh siapa saja tanpa harus memenuhi kualifikasi sarjana hukum sebagai advokat. Perbedaan lainnya terlihat pada target sasaran yang dituju, kalau pada bantuan hukum individual targetnya yaitu masyarakat secara individu sedangkan dalam bantuan hukum struktural targetnya adalah masyarakat dalam arti kolektif.

Pada bantuan hukum individual, ada 2 (dua) cara yang dapat digunakan supaya pelaksanaan bantuan hukum dapat berjalan dengan baik dan mencapai sasarannya yaitu:

1. Memberdayakan organisasi-organisasi masyarakat/swasta yang memberikan jasa bantuan hukum seperti Lembaga Bantuan Hukum (LBH), Lembaga Konsultasi dan Bantuan Hukum (LKBH) ataupun Biro Bantuan Hukum (BBH) yang diadakan oleh universitas-universitas, dan lain-lain. Di sini masyarakat dapat secara langsung atau melalui pengadilan meminta bantuan kepada organisasi masyarakat/swasta tersebut.

2. Memberdayakan organisasi advokat. Pada model ini masyarakat dapat secara langsung atau melalui pengadilan meminta bantuan kepada organisasi advokat dimana nantinya organisasi advokat akan menunjuk anggotanya untuk membela anggota masyarakat yang tidak mampu.
Sementara pelaksanaan bantuan hukum struktural dapat dilakukan melalui 3 (tiga) cara, yaitu:

1. Jalur non-litigasi, dimana lembaga-lembaga bantuan hukum yang ada dan setiap komponen masyarakat yang berkepentingan membantu memberikan pendidikan hukum kepada masyarakat guna menyadarkan mereka akan hak-haknya. Misalnya dengan menempelkan poster-poster di tempat-tempat umum, di institusi-institusi penegakan hukum yang berisi hak dan kewajiban mereka, membuat buklet-buklet yang berisikan informasi mengenai hak masyarakat dan kemudian disebarkan secara umum kepada masyarakat, atau dapat pula secara langsung mengadakan kontak dengan masyarakat melalui diskusi-diskusi yang bertujuan memberikan penyuluhan hukum kepada mereka. Yang intinya adalah meyadarkan masyarakat akan pentingnya hukum yang selama ini masih menjadi milik pemilik modal dan penguasa.

2. Jalur litigasi, di sini para aktifis bantuan hukum yang secara formal menyandang hak berpraktek sebagai advokat menggunakan jalur hukum untuk mengkritisi peraturan perundang-undangan positif yang ada. Misalnya dalam penanganan kasus-kasus politik, forum pengadilan dijadikan sebagai corong dengan persetujuan kliennya untuk menyampaikan pesan ketidak adilan bahwa suatu produk hukum tertentu tidak benar.

3. Policy reform, yaitu mengartikulasikan berbagai cacat yang terdapat dalam hukum positif dan kebijakan yang ada, untuk dikritisi serta kemudian memberikan alternatifalternatif yang mungkin. 


\section{Bantuan Hukum: Langkah yang Terbatas}

Secara konseptual Undang-Undang Bantuan Hukum telah mengadopsi konsep bantuan hukum dan konsep bantuan hukum struktural secara terbatas. Pertama, bantuan hukum diberikan untuk perseorangan "orang miskin" dan kolektif "kelompok orang miskin" yang memohon secara tertulis mapun lisan disertai surat keterangan miskin dari pejabat yang berwenang. Kedua, pemberian bantuan hukum bagi masyarakat miskin dilakukan oleh lembaga bantuan hukum atau organisasi kemasyarakatan yang terverifikasi dan terakreditasi. ${ }^{28}$ Ketiga, bantuan hukum yang diberikan bagi masyarakat miskin yang menghadapi dengan menggunakan jalur litigasi (dilakukan oleh sarjana hukum yang telah memiliki izin beracara di pengadilan) dan non-litigasi (dilakukan oleh paralegal, dosen, dan mahasiswa dari fakultas hukum, fakultas syari'ah, perguruan tinggi militer serta perguruan tinggi kepolisian).

Namun begitu, tidak seorang pun yang bisa mengatakan kebutuhan akan bantuan hukum itu sudah bersifat mendasar. Menurut Todung Mulya Lubis ${ }^{29}$, hal ini disebabkan oleh beberapa masalah. Pertama, belum banyak orang yang tahu tentang lembaga-lembaga bantuan hukum. Kedua, dan ini sangat prinsipil yaitu pada urutan ke berapa bantuan hukum atau hukum ini berada di dalam benak rakyat. Ketiga, secara obyektif kita melihat banyak pintu tertutup bagi bantuan hukum. Keempat, kalaupun bantuan hukum memiliki pintu-pintu terbuka bagi rakyat, maka masih perlu dipertanyakan berapa banyak tenaga bantuan hukum yang tersedia, dan berapa besar anggaran yang tersedia.
Jadi, terdapat banyak keterbatasan dalam bantuan hukum itu sendiri baik secara interen maupun eksteren. Hal ini bisa digambarkan dalam bentuk tabel sebagai berikut:

Tabel 1: Keterbatasan Bantuan Hukum

\begin{tabular}{|ll|ll|}
\hline \multicolumn{2}{|c|}{ Interen } & \multicolumn{2}{|c|}{ Eksteren } \\
\hline 1. & Wawasan & 1. & Wawasan \\
2. & Organisasi & 2. & Kondisi Sosial \\
3. & Tenaga & 3. & Kondisi Politik \\
4. & Dana & 4. & Kebutaan \\
\hline
\end{tabular}

Sumber: diolah Penulis

Semua keterbatasan ini membuat bantuan hukum belum berhak disebut sebagai gerakan. Bantuan hukum baru mengarah ke gerakan, belum lagi menjadi gerakan. Dengan kata lain, baru bisa disebut "organisasi" atau "badan" atau "pos bantuan hukum" sebagai kelompok kekuatan (power resources) yang mengusik-usik kemapanan.

Faktor keterbatasan bantuan yang menarik untuk dicermati adalah dana. Sebab UndangUndang Bantuan Hukum juga mengaturanggaran untuk penyelenggaraan bantuan hukum. Sebagaimana telah penulis kemukakan di atas, bahwa penyelenggaraan dan anggaran bantuan hukum diselenggarakan oleh Mahkamah Agung Republik Indonesia, Kepolisian Republik Indonesia, Kejaksaan Republik Indonesia dan Instansi lainnya. Dengan berlakunya UU Bantuan, maka penyelenggaraan bantuan hukum 'diambil alih' oleh Menteri dan dilaksanakan oleh lembaga bantuan hukum atau organisasi kemasyarakatan. Artinya, UU Bantuan Hukum telah menggeser penyelenggaran dan anggaran bantuan hukum kepada Menteri Hukum dan HAM yang dilaksanakan oleh LBH atau Ormas yang terverifikasi dan terakreditasi.

28 Pasal 7 Undang-Undang Nomor 16 Tahun 2011, Ibid.

29 Todung Mulya Lubis, Bantuan Hukum dan Kemiskinan Struktural, (Jakarta: LP3ES, 1986), hlm. 80-82. 
Permasalahannya, berapa besar dana yang dialokasikan untuk penyelenggaraan bantuan hukum, mulai dari menjalankan kuasa, mendampingi, mewakili, membela, dan/ atau melakukan tindakan hukum lain untuk kepentingan masyarakat miskin. Sebab lembaga bantuan atau organisasi kemasyarakatan berkewajiban dalam memberikan bantuan hukum untuk menangani sampai perkara sampai selesai. Artinya sampai perkara tersebut in kracht (berkekuatan hukum tetap), bisa di pengadilan tingkat pertama, bisa di pengadilan tingkat kedua, bisa di pengadilan tingkat kasasi atau peninjauan kembali. Apakah cukup dengan anggaran sebesar Rp. 5.000.000,- (lima juta rupiah) atau Rp. 6.000.000,- (enam juta rupiah) per kasus? Berapa jumlah LBH atau Ormas berhak menerima anggaran penyelenggaraan bantuan hukum?

Pengalokasian anggaran bantuan hukum yang rasional dan proporsional menjadi penting, sebab ini berkaitan dengan hak penerima bantuan hukum, yaitu mendapatkan Bantuan Hukum hingga masalah hukumnya selesai dan/ atau perkaranya telah mempunyai kekuatan hukum tetap, selama Penerima Bantuan Hukum yang bersangkutan tidak mencabut surat kuasa. ${ }^{30}$

Karena hal ini berkaitan dengan asas efisiensi adalah memaksimalkan pemberian Bantuan Hukum melalui penggunaan sumber anggaran yang ada dan asas efektivitas adalah menentukan pencapaian tujuan pemberian Bantuan Hukum secara tepat. ${ }^{31}$ Apalagi penyelenggaraan bantuan hukum ditujukan untuk: ${ }^{32}$ a. menjamin dan memenuhi hak bagi Penerima Bantuan Hukum untuk mendapatkan akses keadilan;

b. mewujudkan hak konstitusional segala warga negara sesuai dengan prinsip persamaan kedudukan di dalam hukum;

c. menjamin kepastian penyelenggaraan Bantuan Hukum dilaksanakan secara merata di seluruh wilayah Negara Republik Indonesia; dan

d. mewujudkan peradilan yang efektif, efisien, dan dapat dipertanggungjawabkan.

Hal ini perlu disadari penyelenggaraan bantuan hukum sebenarnya mempunyai tujuan ganda, yaitu:

1. Tujuan Kemanusiaan. Bantuan hukum diberikan dalam rangka meringankan beban hidup golongan masyarakat yang kurang mampu, sehingga mereka juga dapat menikmati kesempatan memperoleh keadilan dan perlindungan hukum.

2. Tujuan Peningkatan Kesadaran Hukum. Bantuan hukum diharapkan dapat mendidik masyarakat untuk meningkatkan kadar kesadaran hukum, sehingga setiap anggota masyarakat menyadari dan menghayati hak dan kewajibannya sebagai warga negara dan warga masyarakat.

Di negara berkembang seperti Indonesia, adanya lembaga bantuan hukum atau organisasi kemasyarakatan untuk membantu masyarakat miskin dalam menghadapi masalah-masalah hukum, karena dapat mengurangi kemungkinan masyarakat miskin tidak memperoleh bantuan hukum untuk membela kepentingan hukumnya baik di dalam maupun di luar pengadilan dan

30 Pasal 12 huruf a Undang-Undang Nomor 16 Tahun 2011.

31 Pasal 2 huruf d dan huruf e Undang-Undang Nomor 16 Tahun 2011, Ibid.

32 Pasal 3 Undang-Undang Nomor 16 Tahun 2011. 
dapat membantu masyarakat miskin untuk dapat memperoleh pengetahuan tentang hukum $^{33}$, hak asasi manusia, hak sipil dan politik, hak sosial, hak budaya, dan hak ekonomi.

Bantuan hukum adalah hak dari orang miskin atau kelompok orang miskin yang dapat diperoleh gratis atau tanpa bayar (pro deo/pro bono publico) sebagai penjabaran persamaan hak di hadapan hukum. Karena orang miskin atau kelompok orang miskin adalah menjadi tanggung jawab negara. Terlebih lagi, prinsip persamaan di hadapan hukum (equality before the law) dan hak untuk dibela (access to legal counsel) adalah hak asasi manusia yang perlu dijamin dalam rangka tercapainya pengentasan masyarakat Indonesia dari kemiskinan, khususnya dalam bidang hukum. Selain itu, Pasal 28D menyatakan "Setiap orang berhak atas pengakuan, jaminan perlindungan dan kepastian hukum yang adil serta perlakuan yang sama di hadapan hukum" dan Pasal 28 ayat (2) "Setiap orang berhak mendapat kemudahan dan perlakuan khusus untuk memperoleh kesempatan dan manfaat yang sama guna mencapai persamaan dan keadilan."

\section{E. Penutup}

Keberadaan Undang-Undang Nomor 16 Tahun 2011 belum maksimal memberikan pengaruh terhadap bantuan hukum bagi masyarakat miskin karena masih dalam tatanan formalistik. Sekalipun Bantuan hukum adalah hak dari orang miskin yang dapat diperoleh tanpa bayar (pro bono publico) sebagai penjabaran persamaan hak di hadapan hukum. Tetapi secara konseptual UU Bantuan Hukum baru mengkombinasi beberapa ciri konsep bantuan hukum dari individual dan beberapa ciri konsep bantuan struktural. Dan bantuan hukum dalam UU Bantuan Hukum masih bersifat pasif.

Pendanaan penyelenggaraan bantuan hukum digeser dari Mahkamah Agung, Kejaksaan Agung, dan Kepolisian kepada Menteri Hukum dan HAM yang dilaksanakan oleh Lembaga Bantuan Hukum atau Organisasi Kemasyarakatan agar dapat menyentuh orang atau kelompok orang miskin, tetapi besar anggaran perlu mempertimbangakan proses peradilan yang berjalan. Ini dikhawatirkan dapat menghambat orang miskin dan kelompok orang miskin untuk mengakses keadilan guna mewujudkan hak-hak konstitusional mereka.

\section{DAFTAR PUSTAKA}

\section{Buku}

Haq, Mahbub ul The Poverty Curtain: Choice for the Third World, (New York, Columbia: University Press, 1976)

Lubis, Todung Mulya, Bantuan Hukum dan Kemiskinan Struktural, (Jakarta: LP3ES, 1986).

Lubis, Todung Mulya "Gerakan Bantuan Hukum Di Indonesia: Sebuah Studi Awal" dalam Abdul Hakim Garuda Nusantara Dan Mulyana W. Kusumah, Beberapa Pemikiran Mengenai Bantuan Hukum: Ke arah Bantuan Hukum Struktural, (Bandung: Alumni, 1990).

Lubis, Todung Mulya, "Bantuan Hukum: Arti Dan Peranannya", Prisma No. 6 Tahun II (Desember 1973).

Lubis, Todung Mulya "Pembangunan dan Hakhas asasi Manusia", Prisma, No. 12 (Desember 1979).

Nasution, Adnan Buyung, Bantuan Hukum di Indonesia, (Jakarta: LP3ES, 1981).

Schuyt, C.J.M., Keadilan dan Effektivitas dalam Pembangunan Kesempatan Hidup - penerbitan tidak bertanggal.

Soekanto, Soerjono, dan Mamudji, Sri, Penelitian Hukum Normatif, (Jakarta: Rajawali Press, Jakarta, 1985). 
Soemitro, Ronny Hanitijo, Metodologi Penelitian Hukum dan Jurimetri, (Jakarta: Ghalia Indonesia, 1990).

\section{Internet}

http://hukum.kompasiana.com/2012/08/07/ mengurai-uu-bantuan-hukum-2-483159.html

\section{Peraturan}

Undang-Undang Republik Indonesia, Nomor 16 Tahun 2011, tentang Bantuan Hukum, Lembaran Negara Republik Indonesia, Tahun 2011 Nomor 104, Tambahan Lembaran Negara Republik Indonesia Nomor 5248.
Undang-Undang Republik Indonesia, Nomor 18 Tahun 2003, Tentang Advokat, Lembaran Negara Republik Indonesia Tahun 2003 Nomor 49, Tambahan Lembaran Negara Republik Indonesia Tahun 2003 Nomor 4288

Undang-Undang Republik Indonesia, Nomor 12 Tahun 2011 tentang Pembentukan Peraturan Perundang-undangan.

Peraturan Pemerintah Nomor 83 tahun 2008 tentang Persyaratan dan Tata Cara Pemberian Bantuan Hukum Secara Cuma-Cuma. 